\title{
European species of Arthrolytus Thomson (Hymenoptera: Pteromalidae) reared from cynipid oak galls, with descriptions of two new species
}

\author{
R. R. ASKEW and J. L. NIEVES ALDREY
}

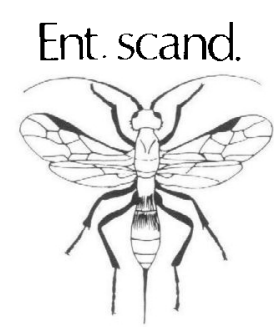
Askew, R. R. \& Nieves Aldrey, J. L.: European species of Arthrolytus Thomsom (Hy-
menoptera: Pteromalidae) reared from cynipid oak galls, with descriptions of two new
species.

Ent. scand. 13: 414-418. Lund, Sweden 15 December 1982. ISSN 0013-8711.

Arthrolytus nanus n.sp. and $A$. incisus n.sp. are described from material reared from cynipid galls on oak, and their systematic positions are discussed. They and $A$. ocellus (Walker) are the first European species of Arthrolytus to be associated with Cynipidae.

R. R. Askew. Dept. of Zoology, University of Manchester, Manchester M13 9PL, England.

J. L. Nieves Aldrey, Departamento de Zoologia, Universidad de Salamanca, Salamanca, Spain.

The palaearctic species of Arthrolytus Thomson are biologically poorly known. Two American species, A. muesebecki Burks, 1969 and $A$. oezbeki Doğanlar, 1978, are associated with cynipid galls (the former with Andricus brunneus Fullaway and Callirhytis quercusagrifoliae (Bassett) on Quercus, the latter, as a hyperparasite, with Diastrophus kincaidii Gillette on Rubus). No European species has hitherto been recorded as parasitic in galls of Cynipidae, although A. glandium Bouček is known to attack larvae of Curculio (Col. Curculionidae) living in acorns (Bouček 1967).

\section{Arthrolytus ocellus (Walker)}

1 o Spain, Salamanca, Teso Santo, ex acorn of Quercus suber L. containing galls of Callirhytis glandium (Giraud) (Hym. Cynipidae), collected 8.iii. 1980. emerged 1-7.iv.1980, leg. J. L. Nieves.

No host has been recorded previously for $A$. ocellus.

\section{Arthrolytus nanus n.sp.}

Figs. 1-7.

Type locality: Spain, Salamanca, Dehesa de Candelario (UTM. - 30T TK6670).
Type material: Holotype $\$$, Spain, Salamanca, Dehesa de Candelario, ex gall of Andricus quercusradicis (Fabricius) of o( Hym. Cynipidae) on Quercus pyrenaica Willd., gall collected 19.x.1979, parasite emerged 1-7.i.1980. Leg. J. L. Nieves, in coll. Brit. Mus. (Nat. Hist.). - Paratypes: 1 \& $20^{\circ}$ same data as holotype; 1 \& 3 on same locality and host as holotype, coll. 4.x.1980, emerged x-xi.1980, leg. J. L. Nieves; I * Spain, Salamanca, Linares de Riofrio, ex gall $A$. quercusradicis coll. 28.iii.1978, emerged 7-15.vi.1978, leg. J. L. Nieves; 1 o" France, Vienne, Poitiers, ex gall Neuroterus albipes (Schenck) ఫุ (Hym. Cynipidae) in second year (1969?) of gall, leg. F. Barbotin; 1 q England, Berkshire, Wytham Wood, from soil under oak trap, 30.vii.1951, G. C. Varley. In colls. BMNH, RRA and Dept. de Zoologia of Universidad de Salamanca. Diagnosis: Antennal structure and head shape place $A$. nanus in the subgenus Anarthrolytus (Graham, 1969) which includes also $A$. ocellus (Walker) and $A$. glandium Bouček. $A$. nanus resembles $A$. glandium and differs from $A$. ocellus in venation, the stigmal vein forming a wide angle to the postmarginal vein (only $20^{\circ}$ to $30^{\circ}$ in ocellus) and being relatively longer (at most only $0.7 \times$ as long as marginal vein in ocellus). The pedicel is very nearly or quite as long as the anelli plus first funicle in $A$. nanus; in $A$. ocellus it is distinctly shorter. From $A$. glandium the new species can be distinguished by its small size (glandium is 2.5-3.0 $\mathrm{mm}$. long), absence, except on hind coxae, of metallic colouration on legs (glandium has metallic femora), relatively shorter malar space $(0.44 \times$ eye length in glandium) and. in the male, by some infuscation below forewing stigma and a basal pale area on the gaster. Derivation of name: in description of its small size.

\footnotetext{
(1) Entomologica scandinavica (HYM 026).
} 


\section{Description}

Female

Head and thorax blue-black, somewhat greenish in parts, dull, scutellum weakly bronzed. Gaster dark brown, basal tergite dark testaceous. Scape whitish, pedicel testaceous with darkened dorsal spot, flagellum brown. Legs stramineous to whitish, only hind coxae on their outer aspects basally metallic, pretarsi brown. Tegulae brown, venation stramineous with infuscation about posterior margin of stigma, wings with a broad, arcuate, light brown band from marginal and stigmal veins almost reaching posterior margin of wing (Fig. 6). Length $1.6 \mathrm{~mm}$.

Head in dorsal view (Fig. 2) $2.1 \times$ as broad as long, temples moderately convergent, forming right angles with occiput, and $0.23 \times$ eye length, POL:OOL as 1.6:1, ocelli in an obtuse triangle with lateral ocelli separated from orbits by about $2.5 \times$ their long diameters; head in frontal view $1.29 \times$ as broad as high; malar space about $1 / 3$ as long as height of an eye; toruli above ventral edges of eyes but much closer to anterior margin of clypeus than to median ocellus, the face strongly receding below toruli, in profile (Fig. 1) appearing protuberant; clypeus (Fig. 3) finely striate, anterior margin shallowly excavated; left mandible with 3 teeth, right with 4 (Fig. 3). Head with strong reticulation and scattered, inconspicuous, short, pale hairs. Antenna (Fig. 5) 11263 , combined length of pedicel and flagellum slightly less than breadth of head; scape not quite reaching lower edge of median ocellus; pedicel about $2 \times$ as long as broad, as long as anelli plus first funicle segment; first anellus much shorter than second; flagellum stout, fusiform, postmortem flattening of the clava making it appear slightly clavate; funicle segments short, the first slightly longer than broad and slightly broader than pedicel, the sixth slightly transverse; placoid sensilla in a single transverse row on each segment, hairs short and stout.

Thorax plus propodeum short, in profile (Fig. 1) $1.25 \times$ as long as high, in dorsal view $1.25 \times$ as long as broad and $0.74 \times$ as broad as head; pronotum short with collar unmargined and curving downwards right from posterior margin; mesoscutum $1.95 \times$ as broad as long, strongly and evenly reticulate with scattered short, robust hairs; scutellum about $1.2 \times$ as broad as long, finely reticulate with elongated areoles medially, the frenum separated by a groove only laterally but clearly defined by its coarser, isodiametric reticulation; dorsellum very short, reticulate. Propodeum medially not quite $0.5 \times$ as long as scutellum, median carina and lateral plicae indicated only anteriorly; median area about $2 \times$ as broad as long, reticulate; callus with many rather short, whitish hairs; nucha not clearly demarcated dorsally, its posterior transverse aciculation merging into anterior reticulation; spiracles small, separated from metanotum by a distance distinctly greater than their major diameters; spiracular sulci absent. Spur of mid tibia almost $0.75 \times$ length of mid basitarsus; tarsi cylindrical; hind femur $3.6 \times$ as long as broad.

Forewing (Fig. 6) reaching just beyond apex of gaster; relative lengths of veins, submarginal 12 , marginal 5, stigmal 4, postmarginal 6 ; marginal vein rather thick; stigmal vein almost straight, forming an angle of about $40^{\circ}$ to submarginal vein, stigma slightly expanded; costal cell with hairs only on lower surface in distal half; basal vein pilose, scattered hairs in distal half of basal cell; speculum open below; disc of wing densely pilose, the hairs very small; apical margin with hairs.

Gaster ovate, about $2 \times$ as long as broad, as broad as thorax. rather longer than rest of body, basal tergite occupying about $0.20 \times$ of total length, apical tergites weakly alutaceous; hypopygium not reaching to middle of gaster; petiole very short, smooth; two pygostylar bristles much longer than the others.

\section{Male}

Resembles female in nonsexual characters; antenna (Fig. 4) slightly longer than in female, pedicel plus flagellum almost as long as breadth of head, flagellar hairs rather longer; forewing (Fig. 7) with the brown band more or less reduced to a spot posterior to stigma, the stigmal vein forming a less acute angle to the postmarginal vein and almost to fully as long as marginal vein; gaster obovate, only slightly longer than broad and shorter than thorax plus propodeum, basal tergite entirely pale testaceous, in some specimens two pygostylar bristles are much longer than the others but these are apparently easily broken. Length $1.2-1.6 \mathrm{~mm}$. 

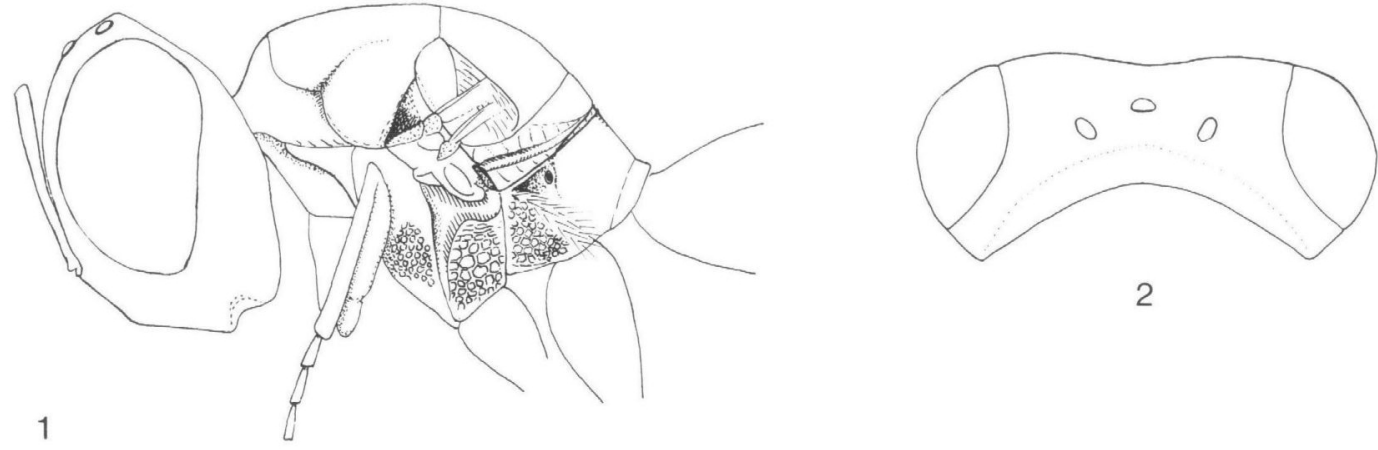

2
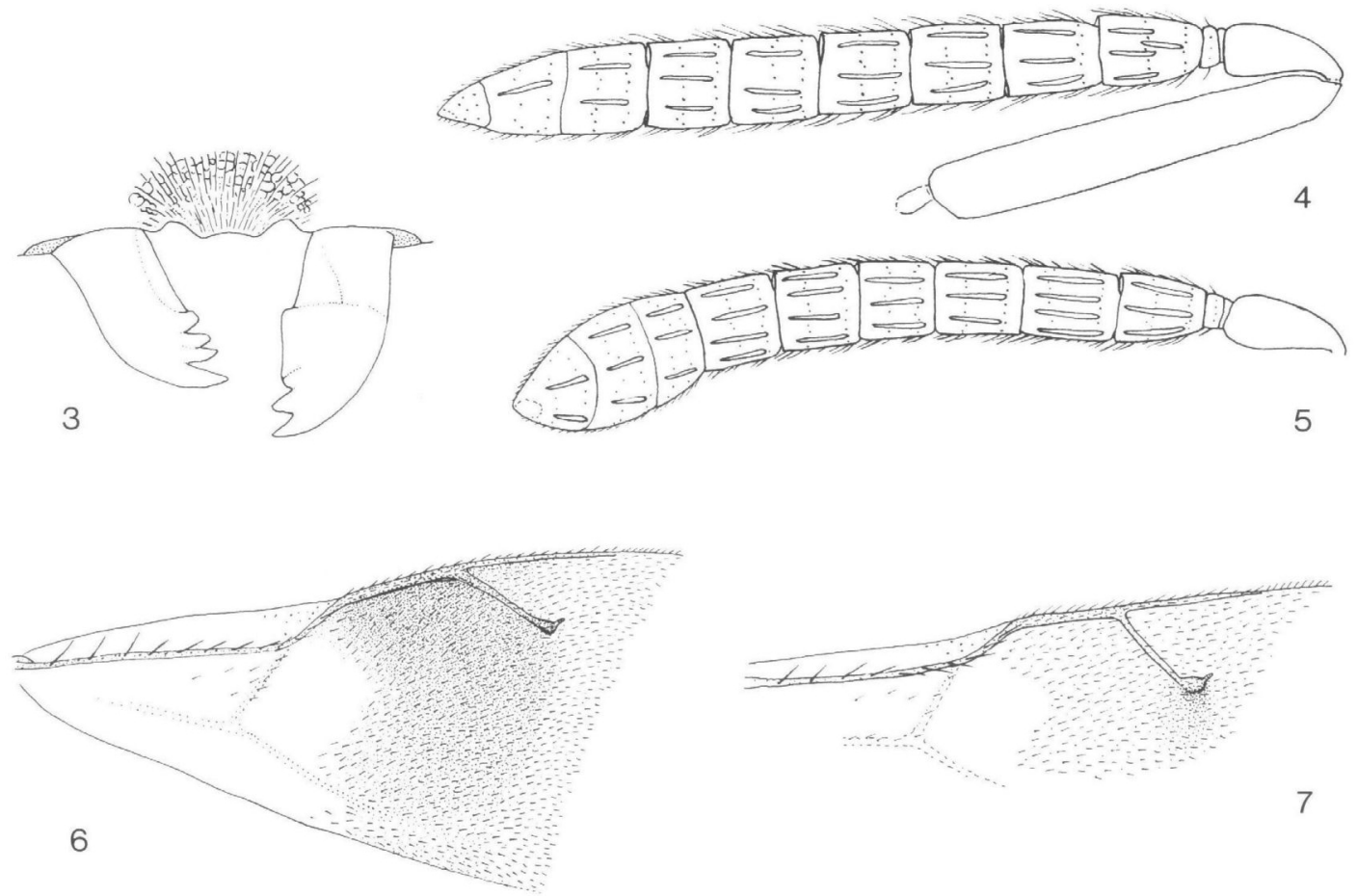

Figs. 1-7. Arthrolytus nanus n.sp. - 1. Female head and thorax from left side. - 2. Female head in dorsal view. - 3. Male clypeus and mandibles. - 4. Male antenna. -5 . Female pedicel and flagellum. -6 . Female right forewing (part). -7 . Male right forewing (part).

\section{Arthrolytus incisus n.sp.}

Figs. 8-13.

Type locality: Spain, Salamanca. Dehesa de Candelario (UTM. - 30T TK6670).

Type material: Holotype ơ Spain, Salamanca, Dehesa de Candelario. ex gall of Andricus quercusradicis (Fabricius) $q$ on Quercus pyrenaica, gall collected 19.x.1979. parasite emerged 7-14.xi.1979. Leg. J. I. Nieves, in coll. Brit. Mus. (Nat. Hist).

Diagnosis: Long, slender antennae inserted far above the ventral edges of the eyes, long flagellar hairs, sub- equal anelli, and only slightly curved lower face indicate affinity with species in the subgenus Arthrolytus s.str. (Graham, 1969) but the incised clypeus and absence of propodeal plicae are anomalous features. Among European Arthrolytus s.str., only A. slovacus Graham has six segments in the male funicle, but the male of slovacus differs from incisus in having a reticulate propodeum with complete plicae, the clypeus not incised, thorax nearly 1.6 times as long as broad, flagellum stouter than pedicel with hairs slightly shorter than the breadth of the funicle segments, imma- 


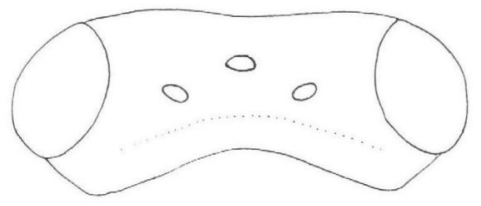

8
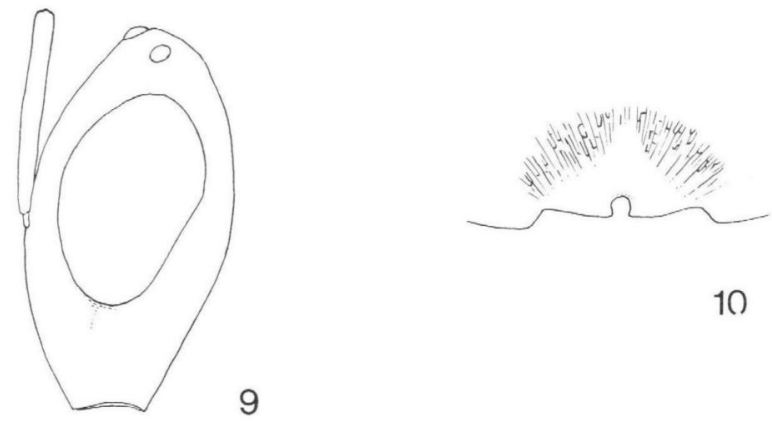

10

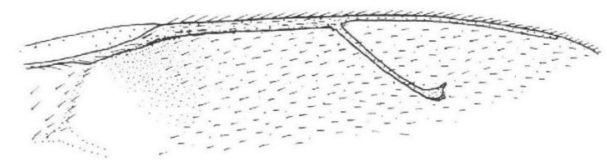

12

11

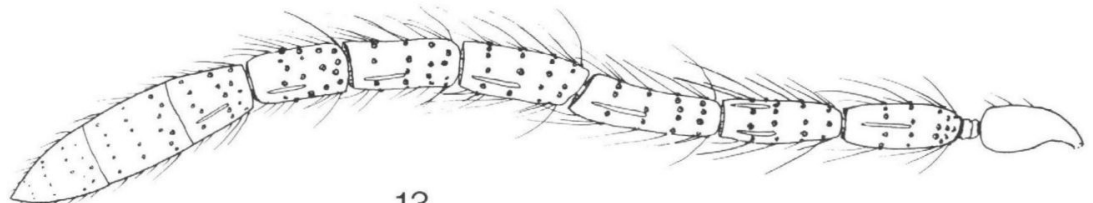

13

Figs. 8-13. Arthrolytus incisus n.sp.. male holotype. - 8. Head in dorsal view. -9 . Head from left side. -10 . Clypeus. -11 . Propodeum. -12 . Right forewing (part). -13 . Pedicel and flagellum.

culate forewing and dorsum of gaster pale only on basal tergite. (A. slovacus occurs in Spain. I Tossa, Gerona, 10.iv.1961, leg. R. R. Askew). All three described American species of Arthrolytus (Burks 1969, Doganlar 1978) have six funicle segments in the males, but they differ from incisus in many respects.

Derivation of name: from the form of the clypeus.

\section{Description}

\section{Male}

Head and thorax blue-black, rather dull, face and scutellum slightly greenish. Gaster with venter and first three tergites yellow. Scape pale testaceous. pedicel testaceous slightly darkened dorsally, flagellum brown. Legs pale testaceous except for brown pretarsi and front and hind coxae which are basally concolorous with tho- rax. Tegulae dark brown, venation light brown, wings hyaline with a weak. brown infuscation posterior to parastigma (Fig. 12). Length 1.8 $\mathrm{mm}$.

Head in dorsal view (Fig. 8) transverse and narrow, about $2.5 \times$ as broad as long, temples strongly convergent and $0.28 \times$ eye length. POL:OOL as 1.8:1. ocelli in a very obtuse triangle with lateral ocelli separated from orbits by about twice their long diameters: head in frontal view $1.27 \times$ as broad as high; malar space about $0.5 \times$ as long as an eye; toruli well above ventral edges of eyes but their lower margins slightly closer to the anterior margin of the clypeus than to the median ocellus: clypeus (Fig. 10) with anterior margin not produced and incised medially, anteriorly smooth. unsculptured. 
Face in profile (Fig. 9) not angled, finely and evenly reticulate with conspicuous scattered, short, white hairs; malar sulcus not defined. Antenna (Fig. 13) 11263, combined length of pedicel and flagellum $1.29 \times$ breadth of head; scape linear without anterior expansion, extending slightly above vertex; pedicel in profile about $2 \times$ as long as broad, shorter than first funicle segment; anelli subequal; flagellum filiform, first funicle segment narrower than pedicel, first three funicle segments all about $3 \times$ as long as broad, the sixth about $2 \times$ as long as broad, clava very slightly broader than funicle segments (postmortem distortion?); placoid sensilla sparse, funicle segments with numerous, moderately outstanding hairs which are distinctly longer than the breadth of funicle segments and which arise from elevated sockets.

Thorax plus propodeum short, only $1.36 \times$ as long as broad and $0.76 \times$ as broad as head in dorsal view; pronotum sloping steeply to neck with collar short and unmargined; mesoscutum $1.75 \times$ as broad as long, notauli distinguishable over $2 / 3 \times$ of its length, strongly and evenly reticulate with scattered, short, white hairs; scutellum slightly broader than long, its areoles rather elongated except on frenum which is poorly differentiated; dorsellum short, smooth. Propodeum (Fig. 11) medially $0.5 \times$ as long as scutellum with distinct median carina and anterior foveae but otherwise almost smooth, shining, plicae absent; callus with many long. white hairs; nucha moderately produced but not separated dorsally from median area of propodeum, with weak aciculate sculpture and indications of reticulation anteriorly; supracoxal flanges rather broad; spiracles separated from metanotum by about their own diameters, spiracular sulcus absent. Spur of mid tibia about $2 / 3 \times$ as long as mid basitarsus; all tarsi cylindrical; hind femur $4 \times$ as long as broad.

Forewing (Fig. 12) extending beyond apex of gaster; relative lengths of veins, submarginal 29 , marginal 16 , stigmal 11 , postmarginal 19; stigmal vein very slightly curved, stigma scarcely expanded; costal cell with one complete line of hairs on undersurface; basal vein pilose; basal cell with scattered hairs in apical quarter; speculum open below; disc of wing densely pilose, the hairs short; apical margin with hairs.

Gaster about as long as rest of body, apical tergites with weak, alutaceous sculpture; petiole small, subconical.

\section{Discussion}

Graham (1969) divides European Arthrolytus into two subgenera and a third subgenus, Anadolytus Doğanlar, 1978, was erected for an American species. A. nanus clearly belongs to the subgenus Anarthrolytus Graham; $A$. incisus has many of the characteristics of Arthrolytus s.str. but it differs from previously described species in several respects. The subgeneric division of Arthrolytus may require future modification, particularly as the present scheme is not fully supported by biological data. Bouček (1967) suggested that Arthrolytus s.str. is associated with grass-dwelling hosts ( $A$. maculipennis (Walker) has been reared from Mayetiola (Dipt. Cecidomyiidae)) and Anarthrolytus with hosts on Quer(us. If $A$. incisus belongs to Arthrolytus s.str., then its association with oak galls confounds this distinction.

\section{References.}

Bouček, Z. 1967. New reared palaearctic Pteromalidae (Hymenoptera). - Acta ent. Mus. Nat. Pragae 37: 635-647.

Burks, B. D. 1969. The North American species of Arthrolytus Thomson (Hymenoptera: Pteromalidae). - Proc. ent. Soc. Wash. 71: 298-303.

Doğanlar, M. 1978. A new species of Pteromalinae (Hymenoptera: Pteromalidae) from western North America. - Can. Ent. 110: 1111-1115.

Graham, M. W. R. de V. 1969. The Pteromalidae of northwestern Europe (Hymenoptera: Chalcidoidea). - Bull. Br. Mus. nat. Hist., Ent. Suppl. 16. $908 \mathrm{pp}$. 